\title{
The Effect of Curriculum Mastery and Work Motivation on Teachers Performance of SMK N Rayon 01 OKU Regency
}

\author{
Rasyid Rido ${ }^{1 *}$, Bukman Lian ${ }^{2}$, Alhadi Yan Putra ${ }^{2}$ \\ ${ }^{1}$ SMKN 1 BP Bangsa Raja Oku Timur, South of Sumatera, Indonesia \\ ${ }^{2}$ Universitas PGRI, Palembang, Indonesia \\ ${ }^{*}$ Corresponding author. Email: rasyidrido33@gmail.com
}

\begin{abstract}
Teacher performance is the capability and teaching skills of teachers. The capability and skills of teachers are manifested in the form of teacher understanding of the curriculum. Curriculum mastery is the ability to differentiate, expand, explain, conclude, give examples, classify operational curriculum concepts compiled and implemented by each academic unit. The more understand the teacher on curriculum, the better teacher's performance has. Another factor that affects teacher performance is work motivation. High work motivation will encourage teachers to work harder and present good work. This research aims at 1) how mastery of curricula affects teacher performance; 2) how it affects teacher performance through motivation of the work; 3.) how it impacts the master's program and how teacher achievement motivations work; This study employs quantitative approaches. Data have been evaluated using SPSS version 23.0 for windows using multiple linear regression algorithm. This research indicates that 1), curriculum mastery has an impact on teacher's success of $29.2 \%$; 2) that job motivation has an impact of $8.8 \%$ on teacher performance; 3 ) that curriculum mastery and teacher motivation have an influence of $27.5 \%$.
\end{abstract}

Keywords: Mastery of the Curriculum, Work Motivation and Teacher Performance

\section{INTRODUCTION}

Education is one of the substantial problems for Indonesia in the current era of globalization. Educational institutions in Indonesia must produce quality human resources and compete competitively to face an increasingly fierce competition between countries in various life activities. Teachers are a vital element in the education system to create quality human resources. All other components, starting from the curriculum, infrastructure, costs, and etc, ill not mean much if not accompanied by adequate teacher quality.

The education system comprises three important elements, namely 1) input, 2) process, and 3) output. Inputs in the education system consist of: students, personnel (including teachers), facilities, finance, school relations with the community, and school climate. The learning process and management in schools will manage these inputs into the expected output, namely students who are high quality and competitive.

The Law of the Republic of Indonesia's National Education System No. 20 Article 18 of 2003 specifies that secondary education continues primary education. High school consists of high school general and secondary technical education. Secondary education consists of high-school education (SMA), Madrasah Aliyah (MA), high-scholastic training (SMK) and Madrasah Aliyah (MAK) or other similar types. The secondary education is the same.

Vocational High Schools (SMK) is a subsystem of formal education organized to prepare middle-level skilled workers. In detail, the mission of implementing SMK is (1) training students for employment and for technical attitudes; (2) preparing students to select jobs and skills; (3) preparing experienced intermediary-level personnel to meet existing and potential labour needs; and ready to develop, adapt, and creative [1].

SMK provides many areas of expertise; one of them is Business and Management expertise. The areas of expertise are divided into accounting, office administration, and marketing majors. To prepare graduates who are skilled, competent, and professional in the fields of Accounting, Office Administration, and Marketing, SMK is required to have teachers who are competent and have high performance.

Teacher output is the extent of teacher achievement in fulfilling their duties in the field of education and 
authorities based on performance standards that have been set for a certain period in the framework of achieving educational goals [2].

The aspect of teacher performance is an important aspect that needs attention. Maintaining and striving for teachers to have high performance is Inecessary to create quality human resources. Efforts to improve teacher performance can be made in various ways; For example, coaching, upgrading, training, or providing opportunities to learn again to increase teachers' competence. It is also necessary to increase discipline, provide motivation and even provide appropriate incentives to enable teachers to feel satisfied at work and their performance continues to increase.

Supposing that teacher performance's success is determined by teacher performance, teachers should have a positive attitude towards the work they are responsible for. These positive attitudes include discipline, responsibility, being severe and continuously improving their quality. However, the reality in the field shows that not all teachers have a good performance.

Performance means an individual or group's degree of achievement in carrying out tasks focused on the performance criteria set for a certain time within the context of organizational objectives, in accordance with its obligations and the authorities [2].

The theory used to assess the quality of teacher performance according to T.R. Mitchcell, namely:

\section{Performance $=$ Motivation $\mathbf{x}$ Ability}

This formula illustrates that a person's performance will be realized by two elements: motivation and ability. Motivation leads to someone doing something to accomplish objectives. motivation Motivation may come from the person and from outside the person [2].

According to Gibson's theory cited by Supardi [3], Three classes of variables, namely: person variables, organizational variables and psychological variables, affect Teacher's success. The research divided individual variables into sub variables of abilities and skill: physical mentality (in this case, curriculum skills and competencies), background: (family, social level, experience), demographics: (age, ethnicity, and type, gender). Organizational variables include: capital, management, incentives, structural arrangement of employment and architecture. Psychological variables include perception, attitude, personality, learning, motivation. Teacher performance is an activity or behaviour that is highlighted by the teacher in carrying out their duties. His professionalism shows his performance in carrying out his profession.

According to Suyud in Sugiyono [4] the Teacher Competency Test (UKG) is intended for teachers who already have a professional certificate, but the results are still far below the minimum standard. As we know, teachers who meet their academic standards or skills ought to increase the standard of education in Indonesia receive professional certificates. However, the facts were not following the government's expectations and plans.

To prepare skilled, competent, and professional SMK graduates, competent and high-performing teachers are needed. It applies in general, including for teachers of SMK Negeri 01 District of East Oku. The conditions in the field regarding the performance of SMK teachers Indicate that the achievement of the highest instructor performance always has challenges or difficulties. Some teachers have been effective and others are not healthy.

Based on the theory of performance, the opinion of Gibson and quoted by Supardi [3] Indicates that three classes of variables influence output to achieve successful performance, namely: individual variables, second organizational variables and three individual psychological variables. In particular, the talents and abilities (mental and physical), familial and social history and demographics are included (age, ethnicity, gender). Corporate factors include money, management, incentives, task layout and architecture. Psychological factors include vision, mood, disposition, apprenticeship, motivation and work satisfaction.

One of the factors that influence teacher performance is the ability and teaching skills of teachers. In this study, teacher's capabilities and skills are manifested in the form of teachers' understanding of the curriculum. Teachers are required to have an understanding and the ability to describe, develop and implement the curriculum. Mastery of the curriculum can distinguish, expand, explain, conclude, give examples, classify operational curriculum concepts compiled and implemented by each academic unit. Teacher understanding in implementing curriculum in Indonesia is necessary to achieve performance following predetermined expectations and standards [3]. If the teacher understands the curriculum well, the teacher's performance should be good too.

Another factor that affects teacher performance is work motivation. Motivation in an individual characterized by feelings emerging is a shift in energy and a response to a target is followed by Mc Donald in Sardiman [5]. Motivation causes energy changes in people such that neurological effects, sensations and impulses continue, then perform or do something. These are all guided by objectives, needs and wants [5]. High work motivation will encourage teachers to work harder so that the results obtained are increased.

One of the variables affecting the national education system is the curriculum. The curriculum must be structured to follow the dynamics that exist in society to achieve national education goals. The curriculum should continue to be updated in line with the realities, changes, and challenges of education in equipping students to become human beings ready to live in various circumstances. The teacher must master the curriculum to support mastery of competencies [6]. 
The curriculum is the period of education that students must take to obtain a diploma. In other words, a curriculum is considered a crucial bridge to reach the end point of a journey and is marked by the acquisition of a certain diploma [7].

With the understanding ability that a person has, both understanding translation, understanding interpretation and understanding extrapolation, that person will be able to relate facts and simple concepts to finally to generalize and draw conclusions. The position of the teacher is very important in curriculum implementation and development. In terms of implementation, the teacher is tasked with actualizing the written curriculum in learning [6]. Some experts state that no matter how good a curriculum the results are, it depends on what the teacher is doing in the classroom [3]. In curriculum development, teachers describe the main curriculum into annual / semester / quarterly programs or study units but also plan, implement, assess and make changes to the curriculum [7].

According to Robbins [8] "motivation is the desire to do something and determine the ability to act to satisfy individual needs". Slamet [9] explains that "motivation is a fundamental psychological process and is one of the elements that can explain a person's behaviour". Based on this understanding, it appears that motivation is related to the strength or drive that is within humans and cannot be seen from the outside. Thus, it can be understood that it is not easy to learn that motivation because motivation cannot be seen, sometimes even unconsciously, different motivations may appear in the form of the same behaviour, and behaviour can be based on several motivations at once.

Meanwhile, Sardiman [5], motivation means something complex about motivation. Motivation can trigger an energy shift in people in order to address the psychiatric effects, thoughts and feelings issue, and either act or do something. All this is motivated by an urge, a desire or a need. According to Sardiman [5], the motivation that exists in everyone has the following characteristics: 1) persevering in facing tasks 2) robust (no swift abandonment of issues), 3) interested in a variety of problems, 4) preferable to autonomous working, 5) boring to repetitive activities fast, 6), being able to protect his views, 7) not readily abandoning everything we believe in, and 8) looking forward to finding and solving problems. (can work constantly, never pause until completion).

To know the work motivation of teachers in this study used measurement indicators derived from the theory of three needs by Mc. Clelland. These indicators are 1) need for achievement, 2) need for power and 3) need for affiliation. This indicator was chosen because it felt the need to be able to motivate the teacher's passion for work.

Based on the problems and the results of previous research that have been described above, it encourages the author to conduct further research on the factors that are thought to affect the performance of the teachers of the District 01 Vocational School of East Oku so that the authors propose the title of the thesis " The Effect of Curriculum Mastery and Work Motivation on Teachers Performance of SMK N Rayon 01 OKU Regency".

\section{METHODS}

Researches will be carried out on teacher success impacts of curriculum interpretation and job incentive at SMK Negeri Rayon 01, East Oku Regency, located in East OKU. By using an experimental method that uses observation and a questionnaire (questionnaire). This study consisted of three variables in the form of two independent variables and a variable that is contingent. In this analysis, the independent variables are curriculum mastery and enthusiasm for work. The reliable variable in the form of teacher success in SMK Negeri 1 radius 1, Oku Regency will be performed in this analysis.

The questionnaire is a research by asking a list of direct research questions, consisting of 24 question items in each variable so that the total number of questionnaires is 72 questions. The scale used is the Likert scale to measure attitudes, opinions and perceptions about social events or symptoms.

Population is a generalized field of objects/themes that researchers have to investigate and then draw conclusions from for certain properties and characteristics [4]. All teachers of SMK Negeri Rayon 01, East Oku Regency were taking the population in this report. 43 teachers are distributed across 3 schools in the academic year 2020/2021.

The sample is part of the number and characteristics of the population. If the population is large, and it is impossible for the researcher to study everything in the population, for example because of limited funds, energy and time, the researcher can use a sample taken from that population [4]. The sample was taken using the purposive sampling technique, namely sampling with criteria [4]. The sample criteria are teachers who are already Strata-1 in the field of Education; because all teachers have been confirmed to have passed the Strata-1, the teachers are worthy of being used as research samples. So, the sample of this research was 43 teachers.

\section{RESULTS AND DISCUSSION}

\section{1) The Effect of Curriculum Understanding and Work Motivation on Teacher Performance at SMK Negeri 01 District of East OKU}

The results of the descriptive analysis show that the performance of the teachers of SMK Negeri 01 District of East $\mathrm{OKU}$ is generally in the medium category of $51 \%$, thus it can be stated that the teachers of SMK 
Negeri 01 District of East OKU have fulfilled the ten basic abilities of teachers according to Sardiman [5]. This means that the teachers of SMK Negeri 01 District of East OKU: (1) master the subject matter; (2) Managing teaching and learning programs; (3) management of classroom performance; (4) use effective learning media; (5) Mastering education foundations; (6) Management of teaching and learning interactions; (7) evaluation of student achievement; (8) familiarity with functions and counselling programs in schooling; (9) identification and organization of school administration; (10) understanding of principles.

The findings of the hypothesis test demonstrate that it is accepted; that is, that there is an effect on the success of the SMK Negeri 01 Teachers from East OKU Regency through curriculum mastery and job encouragement. The instruction predictor, the determinative coefficient $\mathrm{R}^{2}$ for SMK Negeri Rayon 01 's teachers, East OK U Regency, is 27,5\%. The study incentive variable is $27,5 \%$. This study's result implies that the higher the mastery of the curriculum and work motivation, the better the teacher's performance will be. The influence of curriculum mastery and work motivation of the teacher has a contribution of $27.5 \%$ to the formation of teacher performance in the District 01 Vocational School of East OKU Regency.

\section{2) The Effect of Curriculum Mastery on Teacher Performance at SMK Negeri 01 District of East OKU}

The results of the descriptive analysis show that the curriculum mastery of the SMK Negeri Rayon 01 of East OKU Regency is included in the very high category of $29.28 \%$. This reflects that the mastery of the curriculum of SMK Negeri 01 Rayon in East OKU Regency is good, this means it also indicates that SMK Negeri Rayon 01 Regency East OKU has: (1) develop professionalism and development, in a sustainable way through reflection, (2) by using information and communication technologies for their development; (3) mastering the material, structure, concepts and scientific thinking supporting economical subjects; (4) mastering skills and core competencies for economic topics, (5) developing creative economic learning materials.

The measures of the use of information and communication technologies grow out of the five technical skill indicators that have the lowest mean. Descriptive figures indicate however that the use of information and communication technologies in the higher tier has averaged $80,38 \%$, efforts to optimize mastery of the curriculum, especially the use of technology and communication, are still needed.

The results of the hypothesis test show that it is accepted, there is an effect on the success of SMA Kota Tegal professors from the master's course. The curriculum mastery variable has a partial determination coefficient $\left(\mathrm{R}^{2}\right)$ on the performance of the teachers of SMK Negeri Rayon 01 of East OKU Regency of 29.2\%. The findings of this analysis suggest that the greater the program mastery, the more the instructor performs. This is in line with the opinion of Vroom in Mulyasa [10] which states that "performance $=($ ability x motivation $) "$. According to this model, performance is a multiplication function between ability and motivation. If one of these elements is weak then the result of multiplication (performance) will also show unfavourable results.

\section{CONCLUSION}

Based on the results of data analysis and descriptions in the previous chapter, the following conclusions can be drawn: a) understanding the curriculum and work motivation affects SMK Negeri 1 Rayon perforamance, East OKU Regency; b) understanding the curriculum has an effect on the performance of the teachers of SMK Negeri 01 Rayon of East OKU Regency, and 3) work motivation affects SMK Negeri 01 Rayon of East OKU Regency performance.

\section{ACKNOWLEDGMENTS}

Our deepest gratitude goes to Teachers in SMKN 1 BP Bangsa Raja Oku Timur, Chancellor of Palembang PGRI University, Director of the Postgraduate Program of PGRI Palembang University and the Education Management Study Program of PGRI Palembang University, who have supported us in doing this extraordinary thing. This project is funded independently. We also want to thank our Education Management friends who helped us a lot in a short time frame to complete this project.

\section{REFERENCES}

[1] Depdiknas. (2003). Undang-Undang Nomor 20 Tahun 2003 tentang Sistem Pendidikan Nasional. http://www.depdiknas.go.id.(6 Juli 2020).

[2] Barnawi \& Arifin, M. (2012). Kinerja Guru Profesional. Yogyakarta: Ar- Ruzz Media.

[3] Supardi. (2013). Kinerja Guru. Jakarta: Rajawali Pers.

[4] Sugiyono. (2010). Metode Penelitian Pendidikan. Bandung: PT. Alfabeta.

[5] Sardiman. (2011). Interaksi dan Motivasi Belajar Mengajar. Jakarta: Rajawali Pers.

[6] Kunandar. (2007). Guru Profesional: Implementasi Kurikulum Tingkat Satuan Pendidikan (KTSP) dan Sukses dalam Sertifikasi Guru. Jakarta: PT Raja Grafindo Persada.

[7] Hamalik, O. (2008). Kurikulum dan Pembelajaran. Jakarta: Bumi Aksara. 
[8] Robbins, S. P., \& Judge. (2002). Perilaku Organisasi. Jakarta: Salemba Empat.

[9] Slameto. (2010). Belajar dan Faktor-Faktor yang Mempengaruhinya. Jakarta: Rineka Cipta.

[10] Mulyasa, E. (2013). Manajemen Dan Kepemimpinan Kepala Sekolah [Management and Leadership Principal]. Jakarta: Bumi Aksara. 